\title{
The contribution of life and non-life insurances on ASEAN economic growth
}

\author{
Karin Amelia Safitri ${ }^{*}$
}

${ }^{a}$ Study Program of Insurance Administration and Actuary, University of Indonesia Jalan Akses Vokasi, Beji, Kampus UI, Depok, Jawa Barat 16242, Indonesia

\section{H R O N I C L E}

\section{Article history:}

Received: March 12, 2019

Received in revised format: April 102019

Accepted: April 14, 2019

Available online:

April 14, 2019

Keywords:

Economic Growth

Fixed Effect

Insurance Density

Insurance Penetration

Insurance Premium

ASEAN countries

\begin{abstract}
A B S T R A C T
ASEAN is one of the regions with great potential of the world economic power. Countries included in the association of Southeast Asian countries are predicted to show strong economic growth. There are many factors for the development of the ASEAN region such as insurance industry. The Southeast Asian insurance industry, with a stable and long-term financial asset commitment, could play a bigger role in supporting the region's overall economic growth. This study aims at investigating the contribution of the insurance sector measured by three parameters; namely insurance penetration, insurance density and premium volume. The research was conducted to investigate the factors which are related to the insurance industry and could affect the economic growth of 6 countries; namely Singapore, Malaysia, Philippine, Thailand, Vietnam and Indonesia, in ASEAN area over the period 2005-2015 using a fixed effect model. The result revealed that premium volume of life insurance and non-life insurance, respectively, maintained positive and significant effects on the economic growth. Life insurance penetration and density also give significant effects on economic growth while non-life insurance penetration and density are not statistically significant for the economic growth.
\end{abstract}

\section{Introduction}

In recent years, ASEAN countries have accelerated economic growth. Increasing economic growth is very important not only in ASEAN region but also in other countries. The World Bank describes the economies of developing countries in ASEAN were strengthen faster in 2017 and 2018 because of different factors. Many previous studies have shown a significant influence of the development of the financial sector on economic growth in other countries. As Sofia Anwar (2011) points out, Pakistan's economic development was positively influenced by the financial sector both in the short and long-term using the ARDL approach. Mutlugün (2014) illustrates that there is only a short-term relationship between the development of the financial sector and economic growth, but there is no long-term relationship of the two variables in Turkey. The financial sector itself is a sector composed of companies that provide financial services to commercial and retail customers, including investment fund companies, banks, insurance and so forth. The more productive the financial sector of a country, the higher the economic growth. Like banks and other investment companies, the insurance industry is one part of the financial sector that plays

* Corresponding author

E-mail address: karinka1803@gmail.com (K. A. Safitri) 
an important role in encouraging and enhancing a country's economic growth (U1 Din et al., 2017) either directly or indirectly. In addition, life insurance products encourage long-term savings and large-scale investment in public and private sector projects (Beck \& Webb, 2002). Of course, this also has implications for increasing economic growth. Life insurance and non-life insurance are two different types of insurance in providing benefits to its customers based on the types of risks. This automatically affects the impact on economic growth, i.e. non-life insurance leads to short-term protection offering medium and short term indemnigation products.

The growth of the insurance business development can be measured from three parameters: insurance premium volume, insurance penetration and insurance density. The majority of research has been accomplished on insurance and economic growth in developed countries but the results of these studies cannot be generalized. This study focuses on insurance and economic developments in majority of developing countries in the ASEAN region. This research was conducted to investigate what factors are related to the insurance industry that affect the economic growth of 6 countries; namely Singapore, Malaysia, Philippine, Thailand, Vietnam and Indonesia in ASEAN area from 2005 to 2015. Previous research that discusses the positive influence of net premium of life and non-life insurance in Indonesia on economic growth was performed by Nizar (2016). Nizar explained that Indonesia's life insurance premium has started to give positive influence to the country's economic growth from the second year and lasted for 7 (seven) years, while non-life insurance premium started to give positive influence to the economic growth of Indonesia from the second year and lasted for 4 years. The results of this study can be used by policy makers in each ASEAN countries to be more attentive to the development of the insurance industry because of its relationship to economic growth so that insurance companies can improving their activities.

\section{Literature Review}

Many studies related to the relationship between economic growth and insurance industry has been investigated in many ways by many researchers around the world. Every researcher found some empirical result in different ways based on what the country or the parameters of insurance they investigated. This study discussed the contribution of insurance measured by three parameters i.e. insurance penetration, insurance density, and premium volume. Chen $(2012,2018)$ found that there was a non-linear relationship between life and non-life insurance premiums and real income per capita. The impacts of real GDP on life and non-life insurance premiums were presented in shaped and U-shaped patterns, respectively. The study presented the fact that income elasticity of insurance depends on real income per capita level. Some previous studies support the view that real income may affect insurance market, but the conclusion drawn from the empirical findings suggests that such a relationship exists via a non-linear framework. The results show that biased and inconsistent results might be obtained by using the linear insurance premiums models. Pradhan et al. (2017) found mixed some evidence on the relationship between insurance market density and economic growth in the Eurozone countries, both at the individual country level and at the panel setting. On some occasions, insurance market density leads to economic growth, lending support to supply-leading hypothesis of insurance market-growth nexus. On other occasions, economic growth leads to insurance market density, providing support to demandfollowing the hypothesis of insurance market-growth nexus. The analysis method of this study used fixed effect model. Similarly, Han et al. (2010) also explored the relationship between insurance and economic growth for 77 countries over the period 1995-2004 using generalised methods of moments (GMM). Chau et al. (2013) conducted an analysis in Malaysia by looking into the short-term and long-term relationships of life and non-life insurance on economic growth over the 32-year period ended 2012. The authors implemented the Granger co-integration and causality models and found that Life insurance premiums were supplemented by labor which has a significant influence on Malaysia's economic growth in short term. Whereas non-life insurance premiums, employment, capital and the lag of GDP had a significant long relationship with economic growth in Malaysia. The authors found that the relationship between insurance and economic growth was only significant in the short term, while the study conducted by Ching et al. (2010) found a significant relationship between insurance and economic growth. Mohy ul 
din et al. (2017) suggested that for the Malaysian market, legislators must overcome problems caused by non-life insurance such as fraudulent practices. Efforts must be made to have effective and efficient pricing and strict statistical analysis of policy holders.

\section{Methodology/Materials}

\subsection{Data}

This research utilized the annual secondary data which is a panel data accessed from the World Bank. The study analyzes the sequence data taken from 2000 to 2015 . The variables used in this research are the gross premium earned, the number of policy, income per capita, and rate of inflation. Those variables are numeric. Table 1 describes the measurement and source of data for each regressor depicted in Eqs $(1-3)$.

\section{Table 1}

Variable Definition and Measurement of Data

\begin{tabular}{lllll}
\hline No & Abbreviation & \multicolumn{1}{c}{ Variables } & \multicolumn{1}{c}{ Measurement } & Unit \\
\hline 1 & ECG & Economic Growth & Gross Domestic Product (GDP) & Percentage \\
2 & LPN & Life insurance penetration & The ratio of Life Insurance Premium and GDP & Percentage \\
3 & LID & Life insurance density & The ratio of Life Insurance Premium and population & Million Dollar \\
4 & LPM & Life insurance premium & The volume of Life insurance premium & Million Dollar \\
5 & NLP & Non-life insurance penetration & The ratio of Non-Life Insurance Premium and GDP & Percentage \\
6 & NLD & Non-Life Insurance Density & The ratio of Non-Life Insurance Premium and population & Million Dollar \\
7 & NPM & Non-Life Premium & The volume of Non-Life insurance premium & Million Dollar \\
8 & LBR & Labour & Labor force, total & Percentage \\
9 & FIV & Foreign investment & Foreign direct investment, net inflows (\% of GDP) & Percentage \\
10 & EXG & Export growth & Exports of goods and services (annual \% growth) & Percentage \\
11 & DCR & Domestic Credit & Domestic credit to private sector by banks (\% of GDP) & Percentage \\
\hline
\end{tabular}

In this study, the relationship between insurance parameters and economic growth variables are seen by considering the following regression equation:

$$
\begin{aligned}
& E C G_{i t}=\alpha+\beta_{1} L P N_{i t}+\beta_{2} N L P_{i t}+\beta_{3} L B R_{i t}+\beta_{4} F I V_{i t}+\beta_{5} E X G_{i t}+\beta_{6} D C R_{i t}+v \\
& E C G_{i t}=\alpha+\beta_{1} L I D_{i t}+\beta_{2} N L D_{i t}+\beta_{3} L B R_{i t}+\beta_{4} F I V_{i t}+\beta_{5} E X G_{i t}+\beta_{6} D C R_{i t}+v \\
& E C G_{i t}=\alpha+\beta_{1} L P M_{i t}+\beta_{2} N P M_{i t}+\beta_{3} L B R_{i t}+\beta_{4} F I V_{i t}+\beta_{5} E X G_{i t}+\beta_{6} D C R_{i t}+v
\end{aligned}
$$

Note : $\alpha$ is an intercept of regression model, $v_{i}$ is the random effect of country approached to be fixed and $\beta_{i}$ is a parameter.

Following hypothesis can be framed based on the literature reviewed presentedin a previous section.

a. H1.1: Life Insurance Penetration significantly affects economic growth.

b. H1.2: Life Insurance Premium significantly affects economic growth.

c. H1.3: Life Insurance Density significantly affects economic growth.

d. H2.1: Non Life Insurance penetration significantly affects economic growth.

e. H2.2: Non Life Insurance premium significantly affects economic growth.

f. H2.3: Non Life Insurance density significantly affects economic growth.

Here labour force, foreign investment, export growth and domestic credit are the additional variables that have been analyzed as well.

\subsection{Variables Related to Economic Growth}

\subsubsection{Life and Non-Life Insurance Penetration}

Life and non-life insurance penetration refers to a life and non-life insurance product's sales volume relative to the sales volume of competing products. This is usually expressed as the ratio of life and nonlife insurance premiums to other economic measures such as Gross Domestic Product (GDP). According 
to Din et al. (2017) life insurance penetration has positive and a significant relationship with economic growth in a developing/emerging countries. Another study from Kjosevski (2011) explained that nonlife insurance sector positively affects economic growth. Therefore, in this study the relationship between the life and non-life insurance penetration and economic growth is expected to be positive.

\subsubsection{Life and Non-Life Insurance Density}

Life and non-life insurance density refers to a product's number of customers in a area geographically (country, state, city etc.). This is usually expressed as a ratio of life or non-life insurance premium to population. Pradhan et al. (2017) showed there is a unidirectional causality from life insurance market density to economic growth (GDP) for the countries e.g Belgium, Cyprus, Estonia, Finland, Latvia, Lithuania, Luxembourg, Malta, the Netherlands, and Portugal. Pradhan also found the unidirectional causality from non-life insurance market density to GDP in Cyprus, France, Lithuania, Luxembourg, the Netherlands, and Slovenia. Therefore, in this study the relationship between the life and non-life insurance penetration and economic growth is expected to be positive.

\subsubsection{Life and Non-Life Insurance Premium Volume}

Cristea et al. (2014) revealed that life and non-life insurance seperately with its gross written premiums positively contributes as different indepedent variables to economic growth. Njegomir and Stojić (2010) also explained that gross written premiums has a positive effect on economic growth. This study hypothesized that the relationship between the life and non-life insurance premium volume, respectively, and eonomic growth were positive.

\subsubsection{Domestic Credit}

According to World Bank, domestic credit refers to lending or credit that a country or territory's central bank makes it available to borrowers within the same territory. This may include commercial banks and even involve the government itself. Oehler-sincai (2008) revealed that domestic credit does not only contribute positively to economic growth in Nigeria, but the impact is strong and statistically significant. This study is expected that there was a positive contribution of domestic credit on economic growth.

\subsubsection{Export Growth}

According to Elbeydi et al. (2010), there is a unidirectional causality from total export towards economic growth in Turkey based on the empirical analysis during the period 2006-2015. Therefore, it is expected that the relationship between export growth and economic growth is positive.

\subsubsection{Foreign Investment and Labour}

According to Hussain and Haque (2016), foreign Investment promotes the economic growth significantly. This study hypothesized that foreign and labour give a positive impact on economic growth. Chang et al. (2014) found that the size of the labor force is enlarged by increases in unemployment compensation, which in turn enhances employment and long-run economic growth.

\subsection{Methodology}

This study has a methodology as follows.

1. Explored the data (the variability and mean of each variable in every country were investigated, and plotted diagram of response variable to visualize)

2. Performed the correlation testing among variables e.g. total life and non life premiums, life and non life insurance penetration, life and non life insurance density, foreign investment, labour, domestic product and export growth

3. Built the hypotheses:

g. H1: Life Insurance significantly affects economic growth.

h. H2: Non-Life Insurance significantly affects economic growth. 
4. modelled the data using Fixed Effect Model.

$\boldsymbol{y}_{\boldsymbol{i} t}=\boldsymbol{X}_{\boldsymbol{i}} \boldsymbol{\beta}+\boldsymbol{v}_{\boldsymbol{i t}}$, where $v_{i}$ is the random effect of country approached to be fixed and using fixed effect model which accommodates the correlated response variable using the working correlation matrix : AR(1) in condition of the time series data which was taken covers 11 years. This model is considered because it is able to accommodate the heterogeneity among country effect using dummy variables. Fixed effect model with response variable is normally distributed using identity link function.

5. Evaluated the model and assessing the goodness of fit using deviance and interpreted the results of analysis.

6. Obtained the conclusion of the study.

\subsection{Fixed Effect Model}

In a panel data set, a particular individual samples from time to time is used, and provides several observations on each individual in the sample (Hsiao, 2007). Observing a panel data set is basically to monitor a broad section of subjects over time, and thus allows us to study dynamic, as well as cross sectional, aspects of a problem (Frees, 2004). These statements bring us to the conclusion that the panel data is a combination of cross sectional data and time series that explains two kinds of information; namely information between individual units and between times. Baltagi (2005) mentioned the main advantages of panel data analysis as follows,

1. Overcomes individual heterogeneity,

2. Provides more informative dataset, handles collinearity of variables, controls some types of omitted variables without observing them, obtains the degree of freedom in a bigger amount,

3. Studies comprehensively the dynamics of adjustments,

4. Identifies and estimates effects which cannot be taken into traditional technique (e.g. time series analysis and ordinary linear regression),

5. Reduces bias when estimating because of plenty number observations.

We define the following general panel data model for observation $y_{i t}$ of cross section data $i$ at time $t$

$$
y_{i t}=\boldsymbol{x}_{i t}^{\prime} \boldsymbol{\beta}+\varepsilon_{i t}
$$

where $\boldsymbol{\beta}$ is a vector of slope coefficients with $K \times 1$ where $K$ is the number of explanatory variables, $y_{i t}$ is a response variable observed for individual unit $i$ at time $t, \boldsymbol{x}_{i t}^{\prime}$ is a vector of explanatory variables individual unit $i$ at time $t$ and $\varepsilon_{i t}$ is the error term.

Fixed effect model is a statistical model that represents the observed quantities in terms of explanatory variables that are treated as if the quantities were non-random. Fixed and random effects to respectively refer to the population average and subject specific effects. Fixed effect model which has form as.

$$
y_{i t}=\boldsymbol{x}_{i t}^{\prime} \boldsymbol{\beta}+u_{i t}
$$

where $i$ denoted subject dimension which equals $1,2, \ldots N$. $t$ denotes the time dimension which equals $1,2, \ldots, T$ and with specification of residual components is $u_{i t}=v_{i}+\lambda_{t}+\varepsilon_{i t}$. Model 2 also can be written as.

$$
\boldsymbol{y}=\boldsymbol{X} \boldsymbol{\beta}+\boldsymbol{u}
$$

where $\boldsymbol{u}=\boldsymbol{Z a}+\boldsymbol{\varepsilon}$, 


$$
\mathbf{y}=\left[\begin{array}{c}
\mathrm{y}_{11} \\
\mathrm{y}_{12} \\
\vdots \\
\mathrm{y}_{1 \mathrm{t}} \\
\mathrm{y}_{21} \\
\mathrm{y}_{22} \\
\vdots \\
\mathrm{y}_{\mathrm{NT}}
\end{array}\right] \quad \mathbf{X}=\left[\begin{array}{ccccc}
1 & \mathrm{X}_{112} & \mathrm{X}_{113} & \ldots & \mathrm{X}_{11(\mathrm{k}+1)} \\
1 & \mathrm{X}_{122} & \mathrm{X}_{123} & \ldots & \mathrm{X}_{11(\mathrm{k}+1)} \\
1 & \vdots & \vdots & \vdots & \vdots \\
1 & \mathrm{X}_{1 \mathrm{t} 2} & \mathrm{X}_{1 \mathrm{t} 3} & \ldots & \mathrm{X}_{1 \mathrm{t}(\mathrm{k}+1)} \\
\vdots & \mathrm{X}_{212} & \mathrm{X}_{213} & \ldots & \mathrm{X}_{21(\mathrm{k}+1)} \\
\vdots & \mathrm{X}_{222} & \mathrm{X}_{223} & \ldots & \mathrm{X}_{22(\mathrm{k}+1)} \\
\vdots & \vdots & \vdots & \vdots & \vdots \\
\vdots & \mathrm{X}_{2 \mathrm{t} 2} & \mathrm{X}_{2 \mathrm{t} 3} & \ldots & \mathrm{X}_{2 \mathrm{t}(\mathrm{k}+1)} \\
\vdots & \mathrm{X}_{\mathrm{i} 12} & \mathrm{X}_{\mathrm{i} 13} & \ldots & \mathrm{X}_{\mathrm{i} 1(\mathrm{k}+1)} \\
1 & \mathrm{X}_{\mathrm{i} 22} & \mathrm{X}_{\mathrm{i} 23} & \ldots & \mathrm{X}_{\mathrm{i} 2(\mathrm{k}+1)} \\
1 & \vdots & \vdots & \vdots & \vdots \\
1 & \mathrm{X}_{\mathrm{NT} 2} & \mathrm{X}_{\mathrm{NT} 3} & \ldots & \mathrm{X}_{\mathrm{NT}(\mathrm{k}+1)}
\end{array}\right] \quad \mathbf{u}=\left[\begin{array}{c}
\mathrm{u}_{11} \\
\mathrm{u}_{12} \\
\vdots \\
\mathrm{u}_{1 \mathrm{t}} \\
\mathrm{u}_{21} \\
\mathrm{u}_{22} \\
\vdots \\
\mathrm{u}_{\mathrm{NT}}
\end{array}\right]
$$

where $k$ is the number of explanatory variables.

$\boldsymbol{Z}=\boldsymbol{I}_{\boldsymbol{N}} \otimes \mathbf{1}_{T}$, with $\boldsymbol{I}_{\boldsymbol{N}}$ is an $N \times N$ identity matrix, $\mathbf{1}_{\boldsymbol{T}}$ is a $T \times 1$ vector. $\boldsymbol{Z}$ is matrix of dummies which is included in the regression to estimate $\boldsymbol{\alpha}$ if the parameters are assumed to be fixed (Baltagi,2008).

\section{Results and Findings}

Gross Domestic Product (GDP) is the total value of production of goods and services produced by local citizens or foreigners who are citizen of that countries and live inside and the outside that country per year. GDP is one of the important indicators in the economy and one of the barometers in measuring the economic growth of a country. ASEAN is one of the regions with great potential of world economic power. Countries included in the association of Southeast Asian countries are predicted to show strong economic growth. There are many factors to make ASEAN a developed country. Because ASEAN consists of countries that each has its own independence. Countries in ASEAN region which had been observed into samples data are Indonesia, Malaysia, Philiphine, Singapore, Thailand and Vietnam obtained from World Bank Data.

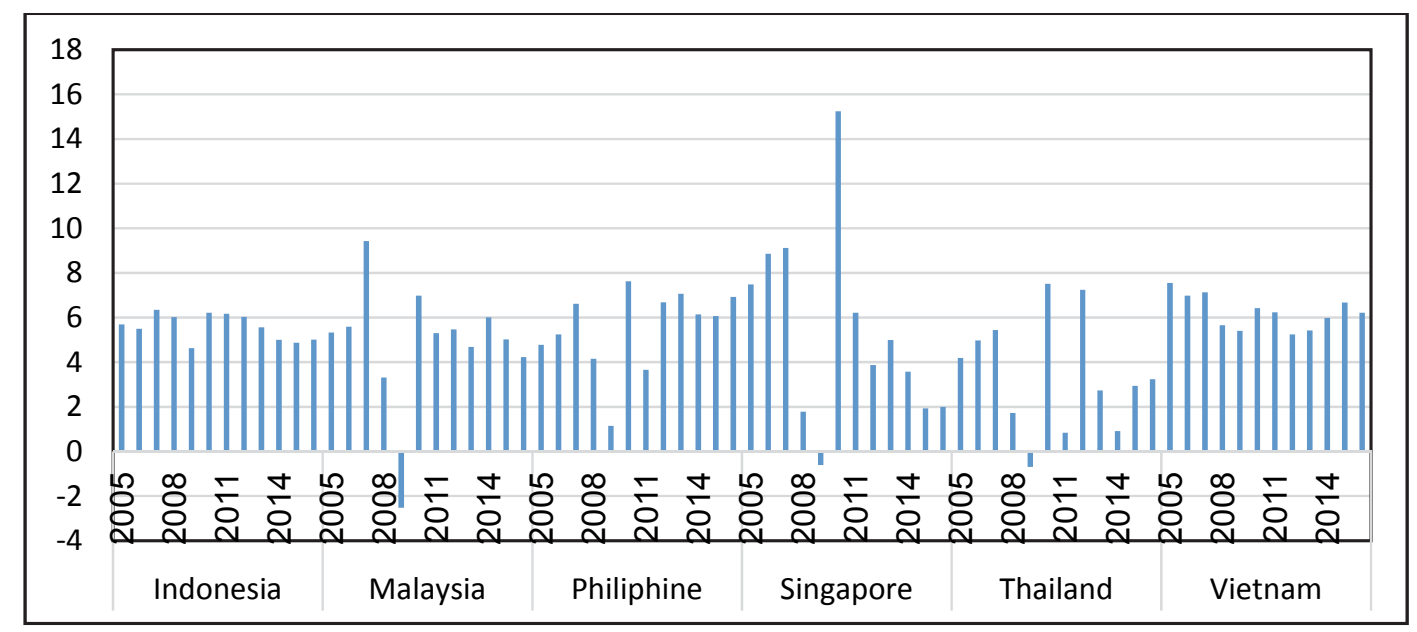

Fig. 1. The Percentage of ASEAN'S GDP

Singapore's real GDP growth comes in at 0.8 percent in the second quarter quarter-on-quarter, adjusted seasonally on an annual basis. While GDP in Thailand if observed from the graph above can be seen to increase despite a decline in 2014 and 2015. The highest GDP in Thailand occurred in 2013, which was USD 6,492,680. GDP in the Philippines tends to increase despite a decline in 2009. The highest GDP in the Philippines occurred in 2015, namely USD 2,882.702 and the lowest in 2009, which was USD $1,871,072$. GDP in Vietnam is steadily increasing every year and there is no decrease of GDP. The highest 
GDP in Vietnam occurred in 2015 at USD 2,109. Growth in the first half of 2016, averaging 2.2 percent year-on-year. In 2017 Indonesia listed its name as a country that can generate GDP value of more than US \$ 1 trillion in a year while Malaysia's economy grew 5.9\% during 2017 compared to $4.2 \%$ recorded in 2016. That number makes Indonesia included in the ranks of 20 countries with the largest GDP in the world.

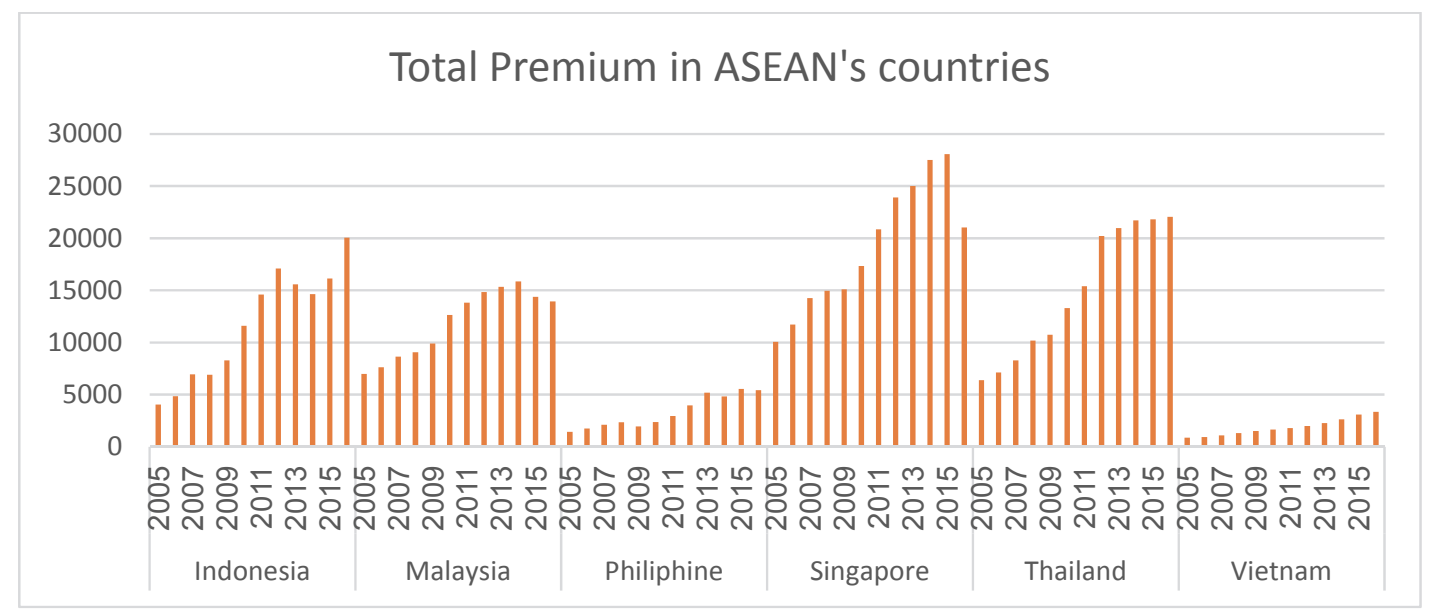

Fig. 2. Total Premium of ASEAN'S Countries

Singapore's real GDP growth comes in at 0.8 percent in the second quarter quarter-on-quarter, adjusted seasonally on an annual basis. Growth in the first half of 2016, averaging 2.2 percent year-on-year. Singapore, Thailand and Malaysia are the region's most developed insurance markets with insurance contributions of 33 percent, 23 percent and 21 percent, respectively. On the other hand, Vietnam and the Philippines recorded the highest gross premium growth of 38.4 percent, 22.6 percent and 10.9 percent, respectively. the ASEAN life insurance market recorded a 3.9 percent increase in premiums to US \$ 68.7 billion in 2015, with Singapore (32.4 percent), Malaysia (22.9 percent) and Thailand (22.1 percent) as contributors greatest. Growth for life insurance, shown by Vietnam (30.1 percent) and the Philippines (13.5 percent). The general insurance market also reported significant growth with a 2.9 percent increase for gross premiums, led by Singapore (33.3 percent), Thailand (24.3 percent) and Indonesia (15.4 percent) as the largest contributors. In terms of growth, Vietnam recorded the highest growth of 13.9 percent respectively.

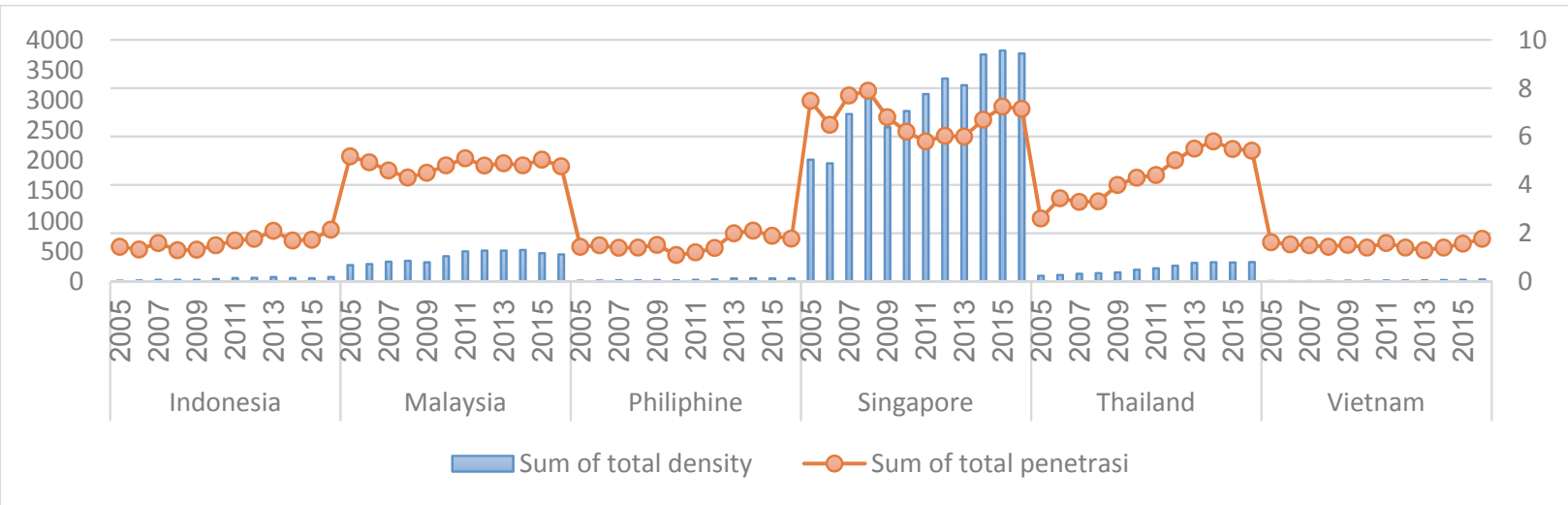

Fig. 3. Insurance Penetration and Density of ASEAN'S Countries

According to the Fig. 3. Insurance penetration in Indonesia is also only 1.7 percent. This value is still lower when compared with Thailand, Singapore and Malaysia where the penetration value of insurance has exceeded 3. Among the 6 countries in the ASEAN region, it is seen that Vietnam is the country with the lowest penetration and insurance density which is then followed by the Philippines. This happens because residents of the country may not be too interested in using insurance in their lives. The insurance development growth is supported by an increase in the number of business actors in ASEAN insurance 
industry in 2015 with a total of 509 insurance companies, up from 2014 of 483 companies. Data from 2015 shows that from insurance industry business side in ASEAN, general insurance still holds the biggest proportion that is $63 \%$ followed by life insurance $(22 \%)$, professional reinsurers $(9 \%)$, composite insurance $(5 \%)$, and owned entity country $(1 \%)$. Under these conditions, regulators and business actors should be able to build the integration of the insurance industry in ASEAN to jointly promote economic growth in the region. The Southeast Asian insurance industry, with a stable and long-term financial asset commitment, could play a bigger role in supporting the region's overall economic growth. From 2012 to 2015, the growth of insurance gross premiums in Southeast Asia reaches an average of 5.8\% per year, which occurs even in the midst of slowing economic growth in some ASEAN countries. We estimated the economic growth regressions on a cross-country and time-series data set consisting of 6 countries and observed between periods 2000-2015. Tables 1 presents basic descriptive statistics for the data used in the regressions model.

\section{Tabel 1}

Descriptive Statistics of Sample Data

\begin{tabular}{lcccc}
\hline Variables & Mean & Standard Deviations & Minimum & Maximum \\
\hline Economic Growth & $3,1164 \mathrm{E}+11$ & $2,1585 \mathrm{E}+11$ & 57633255618 & $9,3225 \mathrm{E}+11$ \\
Life Insurance Premium & 6750 & 4922 & 507 & 17557 \\
Nonlife Insurance Premium & 3719 & 2796 & 352 & 11746 \\
Life Insurance Density & 466 & 860 & 6 & 2932 \\
Nonlife Insurance Density & 161,9 & 264,7 & 4,2 & 919,0 \\
Life Insurance Penetration & 2,343 & 1,645 & 0,6 & 6,300 \\
Nonlife Insurance Penetration & 1,1071 & 0,5563 & 0,4 & 2,200 \\
Labour & 43652218 & 37115367 & 2214093 & 125383640 \\
Domestic Credit & 79,24 & 37,20 & 22,42 & 132,91 \\
Export Growth & 6,024 & 7,228 & $-12,140$ & 20,971 \\
Foreign Invest & 5,890 & 6,850 & 0,057 & 26,521 \\
\hline
\end{tabular}

Because of the standards in the economic growth literature in previous studies, the usual dependent variable is the growth of real GDP per capita in USD. Development of the insurance industry with 3 proxies, namely the volume of insurance premiums, loss insurance and insurance. Other control variables in the regression model include total employment in all countries, domestic credit, export growth, and foreign investment in GDP. Table 2 shows the correlation coefficient between variables.

\section{Tabel 2}

The Coefficient Correlation among Variables

\begin{tabular}{|c|c|c|c|c|c|c|c|c|c|c|c|}
\hline & 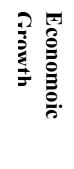 & 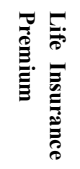 & 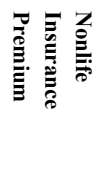 & 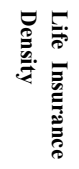 & 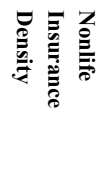 & 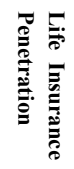 & 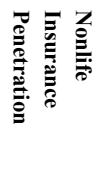 & 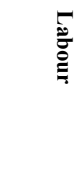 & 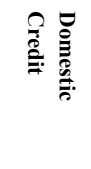 & 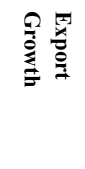 & 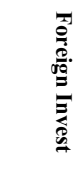 \\
\hline Economoic Growth & 1 & $0,525^{*}$ & $0,294^{*}$ & $-0,129$ & $-0,118$ & $-0,110$ & $-0,187$ & $0,722^{*}$ & $-0,382^{*}$ & $-0,195$ & $-0,229$ \\
\hline Life Insurance Premium & & 1 & $0,874 *$ & $0,579^{*}$ & $0,619^{*}$ & $0,703 *$ & $0,592^{*}$ & $-0,125$ & 0,378 & $-0,348^{*}$ & $0,392^{*}$ \\
\hline Nonlife Insurance Premium & & & 1 & $0,642^{*}$ & $0,716^{*}$ & $0715^{*}$ & $0,687^{*}$ & $-0,294^{*}$ & 0,512 & $-0,255^{*}$ & $0,497^{*}$ \\
\hline Life Insurance Density & & & & 1 & $0,982 *$ & $0,827^{*}$ & $0,462 *$ & $-0,535^{*}$ & 0,434 & $-0,080$ & $0,884^{*}$ \\
\hline Nonlife Insurance Density & & & & & 1 & $0,814^{*}$ & $0,529^{*}$ & $-0,561^{*}$ & 0,497 & $-0,117$ & $0,885^{*}$ \\
\hline Life Insurance Penetration & & & & & & 1 & $0,777 *$ & $-0,660^{*}$ & 0,604 & $-0,206$ & $0,678^{*}$ \\
\hline Nonlife Insurance Penetration & & & & & & & 1 & $-0,665^{*}$ & 0,813 & $-0,224$ & $0,348^{*}$ \\
\hline Labour & & & & & & & & 1 & $-0,685^{*}$ & 0,076 & $-0,493^{*}$ \\
\hline Domestic Credit & & & & & & & & & 1 & $-0,096$ & $0,448^{*}$ \\
\hline Export Growth & & & & & & & & & & 1 & 0,110 \\
\hline Foreign Invest & & & & & & & & & & & 1 \\
\hline
\end{tabular}

The explanatory variables are the development of insurance proxied by the volume of life insurance premiums, the volume of non-life insurance premiums (loss insurance), the ratio of life insurance premiums to GDP, the ratio of life insurance premiums to the population, the ratio of non-life insurance premiums to GDP and the ratio non-life insurance premiums (property-liability insurance) to the population. These steps can be considered as a proxy for insurance activities in the economy. Table 3 shows the coefficients of both life and non-life insurance premiums, penetration and density to GDP. In this study, Insurance sector was measured by using three different proxies such as premium volume, 
penetration rate and density. The result revealed premium volume of life insurane and non-life insurane, respectively, are positively significant to the economic growth.

Table 3

The Coefficient of Fixed Effect Model

\begin{tabular}{lccc}
\hline \multicolumn{1}{c}{ Variables } & Premium Volume & $\begin{array}{c}\text { ASEAN Region } \\
\text { Insurance Penetration }\end{array}$ & Insurance Density \\
\hline Life insurance & $0.5665^{*}$ & $0.3943^{*}$ & $0.3692^{*}$ \\
Non-Life Insurance & $0.0771^{* *}$ & 0.1298 & 0.0477 \\
Labour & $4.4976^{*}$ & $3.9212^{*}$ & $4.2048^{*}$ \\
Domestic credit & -0.0715 & -0.2125 & -0.3393 \\
Foreign invest & 0.0138 & 0.0746 & -0.0166 \\
Export growth & 0.0504 & -0.0852 & $-0.0955^{* *}$ \\
\hline
\end{tabular}

*) represents significance at $5 \%$ respectively

**) represents significance at $10 \%$ respectively

Cristea et al. (2014) revealed that life and non-life insurance seperately with its gross written premiums positively contributes as different indepedent variables to economic growth. Labor force variable has also a positive contribution on economic development. Both for insurance penetration and density only life insurance which is proven having a significant effect on economic growth. This is occured based on the increase of in the number of business actors in ASEAN Life insurance industry. Penetration and density of Non-life insurance market do not meet any signficance value. Many factors made this happened on ASEAN (most countries in that region are classified as developing countries). In addition, the public has not been very familiar with non-life insurance. The underwriting process in non-life insurance is also not maximized. According to Arena (2006) that non-life insurance has a significant effect in high-income countries than in developing ones. So the government as policy maker can pay more attention to the existence of this non-life insurance industry. However, an insignificant relationship was found between non-life insurance and economic growth when density and penetration is used as a proxy for the insurance industry. Umoren and Joseph (2016) also found an insignificant relationship between non-life insurance and economic growth using penetration proxy.

\section{Conclusion}

The aim of presenting this paper was to provide a systematic assessment of the impact of insurance market activity (life and non-life insurance) on economic growth in ASEAN region. To accomplish this task we utilized measurement of insurance premium volume, penetration, and density as proxies of insurance activity for a set of 6 countries over the period, 2000-2015. The results have revealed that premium volume of life insurane and non-life insurane, respectively, influenced positively on the economic growth. Both the insurance penetration and the density of life insurance were proven to have significant effects on economic growth. This is occured based on the increase of the number of business actors in ASEAN Life insurance industry. Penetration and density of non-life insurance market do not meet any signficance value but the government and insurance policy makers can increase the productivity of non-life insurance.

\section{References}

Adams, S., Irwin, G., Capparelli, D., Gratowski, T., \& Porritt, L. (2015). ASEAN Insurance Markets, (October).

Anwar, S., Shabir, G., \& Hussain, Z. (2011). Relationship between financial sector development and sustainable economic development: Time series analysis from Pakistan. International Journal of Economics and Finance, 3(1), 262-271.

Arena, M., Reinhart, C., \& Vázquez, F. (2006). The lending channel in Emerging economics: Are foreign banks different?(No. w12340). National Bureau of Economic Research.

Baltagi, B. H. (2008). Forecasting with panel data. Journal of Forecasting, 27(2), 153-173. 
Beck, T., \& Webb, I. (2003). Economic, demographic, and institutional determinants of life insurance consumption across countries. The World Bank Economic Review, 17(1), 51-88.

Chang, T., Lee, C. C., \& Chang, C. H. (2014). Does insurance activity promote economic growth? Further evidence based on bootstrap panel Granger causality test. The European Journal of Finance, 20(12), 1187-1210.

Chau, W. H., Khin, A. A., \& Teng, K. L. L. (2013). Economic development cointegration and Malaysian life and general insurance consumption. Australian Journal of Basic and Applied Sciences, 7(10), 538-546.

Chen, P.-F., Lee, C.-C., \& Lee, C.-F. (2012). How does the development of the life insurance affect economic growth? Some international evidence. Journal of International Development, 24, 865-893.

Chen, B.L., Hsu, M., \& Lai, C.F. (2018). Labor Force and Relationship Between Long-run Growth and Unemployment. Accesed on August 1st 2018.

Ching, K. S., Kogid, M., \& Furuoka, F. (2010). Causal relation between life insurance funds and economic growth: evidence from Malaysia. ASEAN Economic Bulletin, 185-199.

Cristea, M., Marcu, N., \& Cârstina, S. (2014). The relationship between insurance and economic growth in Romania compared to the main results in Europe-a theoretical and empirical analysis. Procedia Economics and Finance, 8, 226-235.

Din, S. M. U., Angappan, R., \& Baker, A. A. (2017). Insurance effect on economic growth-among economies in various phases of development. Review of International Business and Strategy, 27(4), 409-427.

Elbeydi, K., Hamuda, A., \& Gazda, V. (2010). The relationship between export and economic growth in Libya Arab Jamahiriya. ... and Applied Economics, XVII(1), 69-76.

Frees, E. W. (2004). Longitudinal and panel data: analysis and applications in the social sciences. Cambridge University Press.

Han, L., Li, D., Moshirian, F., \& Tian, Y. (2010). Insurance development and economic growth. The Geneva Papers on Risk and Insurance-Issues and Practice, 35(2), 183-199.

Hussain, M., \& Haque, M. (2016). Foreign direct investment, trade, and economic growth: An empirical analysis of Bangladesh. Economies, 4(2), 7.

Hsiao, C. (2007). Panel data analysis - advantages and challenges. Test, 16(1), 1-22.

Kjosevski, J. (2012). Impact of insurance on economic growth: The case of Republic of Macedonia. European Journal of Business and Economics, 4.

Mohy ul din, S., Regupathi, A., \& Abu-Bakar, A. (2017). Insurance effect on economic growth - among economies in various phases of development. Review of International Business and Strategy, 27(4), 501-519.

Mutlugün, B. (2014). The relationship between financial development and economic growth for Turkey. İktisat Politikası Araştırmaları Dergisi, 1(2).

Nizar, M. A. (2016). Hubungan antara asuransi dan pertumbuhan ekonomi di indonesia. Akselarasi dan Inkulisivitas Sektor Keuangan: Jalan Menuju Kesejahtraan Rakyat.

Njegomir, V., \& Stojić, D. (2010). Does Insurance Promote Economic Growth: The Evidence From ExYugoslavia Region. Ekonomska Misao I Praksa, 1, 31-48.

Oehler-Sincai, I. M. (2008). Strengths and weaknesses of the New Public Management (NPM)-crosssectional and longitudinal analysis.

Pradhan, R. P., Dash, S., Maradana, R. P., Jayakumar, M., \& Gaurav, K. (2017). Insurance market density and economic growth in Eurozone countries: the granger causality approach. Financial Innovation, 3(1), 17.

Umoren, N. J., \& Joseph, E. M. (2016). Relative contributions of the insurance industry to the growth of the Nigerian economy. International Journal of Emerging Research in Management \& Technology, 5(6), 189-198.

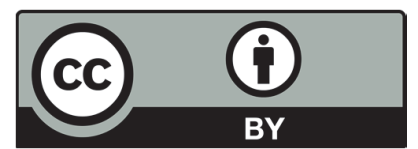

(C) 2019 by the authors; licensee Growing Science, Canada. This is an open access article distributed under the terms and conditions of the Creative Commons Attribution (CCBY) license (http://creativecommons.org/licenses/by/4.0/). 